\title{
PENINGKATAN HASIL BELAJAR SISWA PADA MATERI FAKTORISASI POLINOM MELALUI PENERAPAN MODEL PEMBELAJARAN KOOPERATIF TIPE STUDENT FACILITATOR AND EXPLAINING
}

\author{
Yandry Niak$^{1}$, Jeinne Mumu${ }^{1}$, Anderson Leonardo Palinussa ${ }^{2}$ \\ ${ }^{1}$ Universitas Negeri Papua, Manokwari Papua Barat \\ ${ }^{2}$ Program Studi Pendidikan Matematika, Jurusan MIPA FKIP Unpatti \\ Email: *yandryniak63@gmail.com
}

\begin{abstract}
This study aims to improve student learning outcomes in polynom factorization material using a cooperative learning model type Student Facilitator and Explaining (SFE). This research has qualitative research. The class conducted the action using teaching materials and grup worksheets, which have been adapted to the SFE model and learning is carried out in two cycles. At the end of each cycle a final cycle test is carried out, then the data obtained are analyzed quantitatively and qualitatively. The result of the study showed that there was an increase in the learning outcomes of class XI SMA Negeri 1 Manokwari who were taught to use the SFE type cooperative learning model on polynom factorization material.
\end{abstract}

Keywordsi: Qualitative research, cooperative model, student facilitator and explaining, polynom factorization.

\section{Pendahuluan}

Kurikulum 2013 (K13) mengharuskan siswa harus lebih aktif dibandingkan guru, karena pembelajaran pembelajaran menggunakan K13 harusnya berpusat pada siswa bukan pada guru. Namun kenyataannya tidak sesuai dengan yang peneliti amati selama peneliti melaksanakan Praktik Pengenalan Lapangan (PPL) di SMA Negeri 1 Manokwari kelas XI jurusan Ilmu Pengetahuan Alam (IPA), terlihat bahwa dalam kegiatan pembelajaran guru lebih mendominasi dalam pembelajaran dengan menyampaikan materi menggunakan metode ceramah dan siswa hanya mencatat apa yang disampaikan oleh guru. Seharusnya siswa yang harus menemukan dan memecahkan suatu masalah matematika sendiri, dan guru hanya mengarahkan siswa dalam memahami suatu materi. Dengan demikian hal ini mengakibatkan kemampuan siswa dalam memahami suatu konsep matematika sangat lemah, sehingga berdampak pada hasil ulangan yang diperoleh. Dari hasil ulangan matematika, hanya terdapat 10 peserta didik yang mendapatkan nilai diatas standar kriteria ketuntasan minimal.

Jika seorang pendidik terus menerus melakukan kegiatan pembelajaran dengan cara yang sama, maka hasil belajar siswapun akan tetap sama dan siswa akan mengalami kesulitan dalam menyelesaikan soal-soal matematika dan memecahkan masalah matematika. Sehingga hal tersebut merupakan salah satu faktor yang dapat mempengaruhi rendahnya hasil belajar siswa. Untuk itu, perlu adanya perbaikan terhadap pembelajaran matematika di kelas sehingga hasil belajar siswapun dapat ditingkatkan. Sehubungan dengan itu, maka guru dituntut untuk dapat merancang dan melaksanakan suatu model pembelajaran yang dapat merangsang siswa untuk berpikir dalam menyelesaikan masalah dan siswa selalu memberikan respon positif dalam proses pembelajaran.

Bertolak dari penjelasan di atas, maka perlu dicarikan suatu solusi sehingga siswa dapat belajar kreatif, mempelajari materi dan konsep, mencoba latihan-latihan soal dan adanya komunikasi antar siswa dengan siswa dan siswa dengan guru. Hal tersebut diperlukan agar pembelajaran yang dilaksanakan dapat memberikan hasil yang optimal dan mampu meningkatkan hasil belajar siswa. Salah satu solusi yang dapat digunakan untuk mengatasi masalah tersebut adalah dengan menggunakan model pembelajaran kooperatif tipe Student Facilitator and Explaining.

Model Pembelajaran kooperatif tipe Student Facilitator and Explaining (SFE) merupakan salah satu model pembelajaran inovatif. Menurut Suprijono (2009), dalam model ini siswa belajar mempersentasikan ide/pendapat pada siswa lainnya. Model pembelajaran ini efektif untuk melatih siswa berbicara untuk menyampaikan ide/gagasan atau pendapatnya sendiri. Dengan proses pembelajaran seperti ini siswa dapat meningkatkan keaktifan, minat, motivasi dan kreativitas siswa dalam berpikir sehingga proses belajar akan lebih menarik dan menyenangkan. Model pembelajaran kooperatif tipe student facilitator and explaining lebih cenderung kepada 
kemampuan individual siswa. Siswa lebih dituntut untuk dapat menunjukan kemampuan intelektualnya dalam menjelaskan kepada siswa lain tentang materi yang sedang dipelajari. Model pembelajaran kooperatif tipe student facilitator and explaining merupakan salah satu model pembelajaran yang menekankan bahwa belajar berpusat pada siswa. Model ini memanfaatkan potensi siswa untuk dapat menjelaskan materi yang telah di ajarkan oleh guru. Hal ini dimaksud agar siswa lebih mudah memahami materi yang diajarkan.

Kakerisa (2016), hasil penelitiannya menunjukan bahwa rata-rata kemampuan komunikasi siswa yang diajarkan dengan model student fasilitator and explaining (SFE) sebesar 73,65 sedangkan rata-rata kemampuan komunikasi siswa matematika siswa yang diajarkan dengan metode konvensional sebesar 55,50. Sehingga dapat disimpulkan bahwa terdapat perbedaan yang signifikan antara siswa yang diajarkan menggunakan model pembelajaran kooperatif tipe student facilitator and explaining dan model pembelajaran konvensional. Hal yang sama juga nampak pada penelitian Murfika (2011), hasil penelitiannya menunjukan bahwa rata-rata kemampuan komunikasi siswa yang diajarkan dengan model student fasilitator and explaining (SFE) sebesar 66,5 sedangkan rata-rata kemampuan komunikasi siswa matematika siswa yang diajarkan dengan metode konvensional sebesar 59,12. Sehingga dapat disimpulkan bahwa terdapat perbedaan yang signifikan antara siswa yang diajarkan menggunakan model pembelajaran student facilitator and explaining dan model pembelajaran konvensional.

Penelitian ini merupakan penelitian kuantitatif dengan tipe penelitian tindakan kelas (PTK). Menurut Arikunto, dkk (2006: 57), penelitian tindakan kelas (PTK) adalah penelitian tindakan yang dilakukan di kelas dengan tujuan memperbaiki/meningkatkan mutu praktek pembelajaran. Secara umum tahapan pelaksanaan tindakan setiap siklus dapat di gambarkan sebagai berikut.

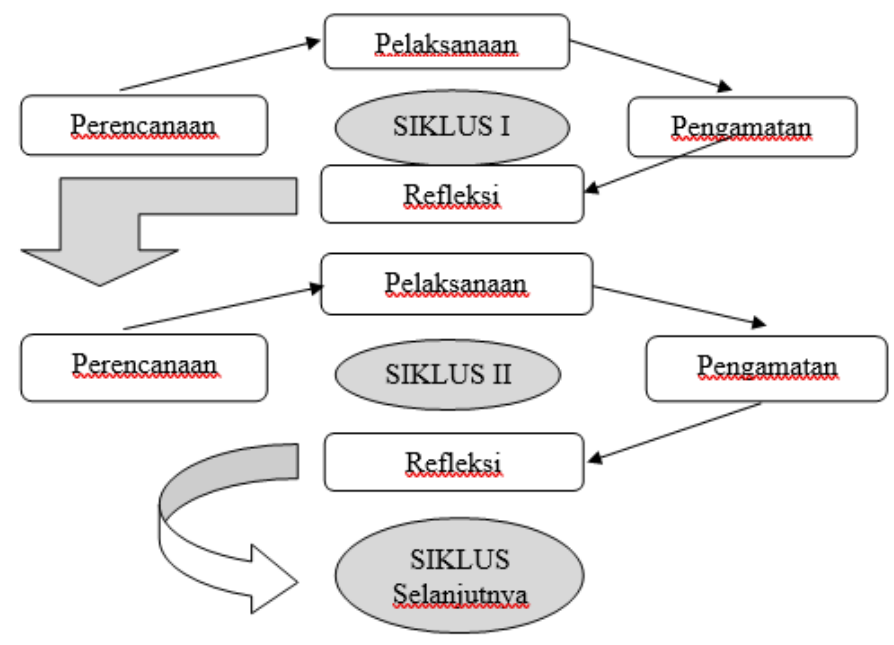

Gambar 1. Siklus Penelitian Tindakan Kelas (Arikunto, dkk. 2006: 57).

Berdasarkan namanya, maka terdapat tiga kata yaitu penelitian, tindakan, dan kelas. Pengertian masingmasing menurut Tanujaya dan Mumu (2016: 4) akan dijelaskan sebagai berikut: Penelitian merupakan poses penyelidikan ilimiah yang dilakukan secara terencana untuk memperoleh fakta guna memperkuat, mengembangkan dan atau membantah sesuatu yang sudah diyakini kebenarannya. Tindakan merupakan aktivitas yang dilakukan untuk terlaksananya pembelajaran efektif dan efisien, sedangkan Kelas dapat diartikan sebagai sekelompok siswa dalam satu lingkaran yang sama yang melakukan aktivitas pembelajaran.

Pengertian PTK sendiri menurut Tanujaya dan Mumu $(2016,7)$ adalah: kegiatan penelitian dalam bentuk siklus yang merupakan suatu tindakan sebagai hasil refleksi seorang guru di kelas yang dikelolanya, dengan tujuan utama untuk meningkatkan kualitas pembelajaran dalam rangka perbaikan dan peningkatan kinerja siswa dalam bentuk prestasi belajar.

Banyak model penelitian tindakan yang telah dikembangkan oleh para ahli dalam bidang penelitian tindakan. Menurut Tanujaya dan Mumu (2016: 17) model-model penelitian tindakan yang telah dikenal antara lain: Model Lewin, odel Kemmis \& Taggart, model Ebbut, model Elliot, model Mc Keman, model Risel, model Taba-Noel, model Lip Radke, model Cheecland, model Sagor, dan model DDAER.

Model Kemmis-Taggart merupakan model yang dikembangkan oleh professor Stephen Kemmis dan Profesor Robyn McTaggart dengan menggunakan konsep dasar pada penelitian tindakan yang diperkenalkan oleh Kurt Lewin. Sama halnya dengan penelitian tindakan Kurt Lewin, penelitian tindakan Kemmis-Taggart juag berbentuk 
spiral. Penelitian tindakan Kemmis-Taggart terbagi dalam tiga bagian utama, yaitu: (1) perencanaan, (2) tindakan dan pengamatan, dan (3) refleksi. Pada penelitian ini aktivitas tindakan dan pengamatan digabung menjadi satu dengan alas an karena kedu akegiatan tersebut dapat dilakukan pada waktu bersamaan. Kemmis dan Taggart beranggapan bahwa pada saat berlangsungnya suatu tindakan dilakukan, kegiatan observasi harus dilakukan sesegera mungkin (Tanujaya dan Mumuu, 2016: 22). Selain tindakan dan pengamatan digabungkan dalam satu aktivitas, pada model Kemmis-Taggart terdapat adanya penekanan aktivitas perencanaan ulang (revised plan). Perpindahan siklus terjadi berawal dari tindakan yang diambil belum memberikan hasil yang maksimal, sehingga membutuhkan perencanaan ulang (Tanujaya dan Mumu, 2016: 22).

Tujuan penelitian ini adalah untuk meningkatan hasil belajar siswa kelas XI IPA-7 SMA Negeri 1 Manokwari tahun pelajaran 2018/2019 pada materi faktorisasi polinom melalui penerapan model pembelajaran kooperatif tipe SFE. Penelitian ini diharapkan dapat memberikan manfat bagi: (1) dunia pendidikan untuk penelitian selanjutnya yang berkaitan dengan penelitian tindakan kelas yang ingin meningkatkan hasil belajar matematika siswa menggunakan model kooperatif tipe Student Facilitator and Explaining, (2) guru, sebagai informasi dalam mengatasi kesulitan yang dihadapi pada proses pembelajaran dan untuk menambah pengetahuan dalam mengefektifkan proses pembelajaran menjadi lebih baik, (3) siswa, dengan menggunakan model mengajar matematika yang berbeda dapat meningkatkan motivasi dan hasil belajar siswa, (3) peneliti, bisa menambah wawasan dalam pengembangan ilmu pengetahuan di bidang pendidikan.

\section{Metode}

Penelitian yang akan dilaksanakan, menggunakan jenis penelitian tindakan kelas. Tujuan utama penelitian tindakan kelas adalah untuk memperbaiki dan meningkatkan kualitas pembelajaran, terutama kualitas isi, proses, dan hasil pembelajaran secara berkesinambungan (Tanujaya dan Mumu, 2016: 14). Sebagai seorang pendidik, permasalahan yang terjadi di kelas sangat bervariasi. Karakteristik siswa yang berbeda-beda dapat menimbulkan berbagai permasalahan. Sudah sepatutnya seorang pendidik mampu mengatasi permasalahan yang ada di kelas. Permasalahan tersebut dapat diatasi dengan cara melaksanakan PTK yang bertujuan agar memperbaiki proses pembelajaran dan mencapai tujuan pembelajaran yaitu memperoleh hasil belajar yang baik.

Model tindakan yang dilakukan yaitu Kemmis-Taggart yang terdapat tiga kegiatan utama pada setiap siklus. Prosedur pelaksanaan tindakan menurut model dari Kemmis-Taggart terlihat pada gambar berikut.

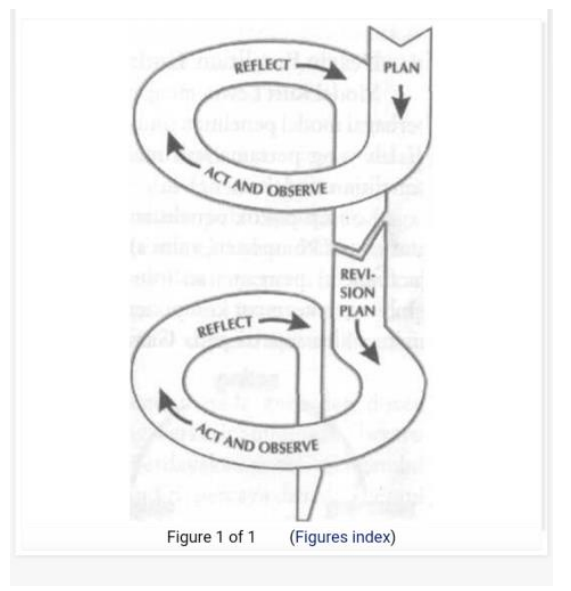

Gambar 2. Model Spiral Kemmis-Taggart.

Penelitian dilaksanakan pada semester genap tahun ajaran 2018/2019, yaitu pada tanggal 07 Maret sampai dengan 03 Mei 2019. Rincian waktu penelitian ditunjukkan dalam tabel berikut.

Tabel 1. Waktu Penelitian

\begin{tabular}{ll}
\hline Hari/Tanggal & Keterangan \\
\hline Kamis, 07 Maret 2019 & Pertemuan I \\
Kamis, 21 Maret 2019 & Pertemuan II \\
Kamis, 11 April 2019 & Tes siklus 1 \\
Jumat, 12 April 2019 & Pertemuan III
\end{tabular}




\begin{tabular}{ll} 
Kamis, 25 April 2019 & Pertemuan IV \\
Jumat, 03 Mei 2019 & Tes siklus 2 \\
\hline
\end{tabular}

Penelitian tindakan ini dilaksanakan di SMA Negeri 1 Manokwari pada siswa kelas XI jurusan IPA-7 tahun ajaran 2018/2019. SMA Negeri 1 Manokwari terletak di Jl. Palapa Reremi, Kecamatan Manokwari Barat, Kabupaten Manokwari, Provinsi Papua Barat.

Populasi dalam penelitian ini adalah siswa SMA Negeri 1 Manokwari tahun ajaran 2018/2019, sampelnya adalah siswa KLS XI IPA SMA Negeri 1 Manokwari tahun ajaran 2018/2019 dan subjek penelitiannya adalah siswa kelas XI IPA-7 SMA Negeri 1 Manokwari tahun ajaran 2018/2019. Perangkat pembelajaran yang digunakan dalam penelitian terdiri dari Rencana Pelaksanaan Pembelajaran (RPP), Bahan Ajar (BA) dan Lembar Kerja Kelompok (LKK) yang disusun sesuai model pembelajaran kooperatif tipe SFE. Rencana Pelaksanaan Pembelajaran dalam penelitian ini terdiri atas 4 RPP.

Teknik pengumpulan data pada penelitian ini adalah tes dan observasi, yang akan dijelaskan sebagai berikut: (1) Tes hasil belajar, diberikan oleh guru secara mandiri kepada setiap siswa pada setiap siklus, dimaksudkan untuk mengetahui hasil belajar siswa setelah melakukan pembelajaran pada materi faktorisasi polinom dengan menggunakan model pembelajaran SFE, (2) Observasi, adalah suatu teknik yang dilakukan dengan cara mengadakan pengamatan secara teliti serta pencatatan secara sistematis. Observasi yang dilakukan dalam penelitian ini adalah melakukan pengamatan secara langsung dalam proses pembelajaran dengan model pembelajaran SFE. Observasi ini dipandu dengan pedoman observasi yang telah dibuat, dan dalam penelitian ini dibentuk 10 kelompok, dan membutuhkan 1 orang observer untuk mengamati aktivitas guru dan aktivitas siswa.

Data hasil penelitian ini akan diolah dengan menggunakan analisis data sebagai berikut: (1) Analisis data kuantitatif, menggunakan statistik deskriptif untuk mengetahui hasil belajar siswa. Rumus yang digunakan menurut Purwanto (2009: 12), yaitu.

$$
\text { Hasil Belajar }=\frac{\text { jumlah skor yang diperoleh }}{\text { jumlah skor total }} \times 100
$$

Selanjutnya, dari hasil belajar siswa kemudian dibandingkan dengan Kriteria Ketuntasan Minimal (KKM) yang telah ditetapkan oleh SMA Negeri 1 Manokwari, yaitu 75.

Tabel 2. Kriteria Ketuntasan Minimal

\begin{tabular}{cc}
\hline Hasil Belajar & Keterangan \\
\hline$\geq 75$ & Tuntas \\
$<75$ & Belum Tuntas \\
\hline
\end{tabular}

Untuk menghitung ketuntasan klasikal atau besarnya persentase siswa yang mencapai KKM, digunakan rumus.

$$
\text { Ketuntasan Klasikal }(\%)=\frac{\text { jumlah siswa yang tuntas }}{\text { jumlah siswa yang mengikuti tes }} \times 100 \%
$$

Menurut Suryosubroto (2002: 77), syarat suatu pembelajaran dikatakan tuntas secara individu maupun klasikal adalah (1) seorang siswa dikatakan tuntas belajar jika siswa tersebut mencapai skor minimal enam puluh lima (2) suatu kelas dikatakan tuntas belajar jika dalam kelas tersebut telah terdapat $65 \%$ dari jumlah seluruh siswa yang telah mencapai daya serap $\geq 65$. Berdasarkan hal inilah, maka dalam penelitian ini suatu kelas dikatakan tuntas belajar jika dalam kelas tersebut terdapat $65 \%$ dari jumlah seluruh siswa telah mencapai KKM. Sedangkan untuk penetapan KKM mengacu pada ketentuan yang ditetapkan sekolah yaitu siswa dikatakan tuntas jika mencapai KKM $\geq 75$. (2) Analisis Data Kualitatif, menurut Miles dan Huberman (Tutuhatunewa, 2007: 43), data kualitatif dianalisis dengan mengikuti tiga tahapan sebagai berikut: (a) Reduksi Data, merupakan suatu proses penyederhanaan yang dilakukan melalui seleksi, pemfokusan, penajaman, penyisihan data yang kurang bermakna, dan menatanya sedemikian rupa sehingga kesimpulan akhir dapat ditarik dan diverifikasi. (b) pemaparan data, adalah proses penampilan data secara lebih sederhana dalam bentuk paparan naratif, tabulasi, matriks, grafik dan lain sebagainya. (c) penyimpulan, adalah proses pengambilan intisari dari sajian data yang telah diorganisasikan dalam bentuk pernyataan atau kalimat singkat dan padat tapi mengandung pengertian yang luas.

Berdasarkan pendapat di atas maka dalam penelitian ini peneliti menggunakanan reduksi data, penyajian atau pemaparan data dan penarikan kesimpulan sebagai berikut: (a) Reduksi data, kelas XI IPA-7 terdiri dari 39 siswa dan setelah data seluruh siswa direduksi maka total siswa yang mengikuti tes akhir siklus 1 dan siklus 2 sebanyak 
27 orang siswa. (b) Penyajian atau pemaparan data, setelah data direduksi kemudian data yang lengkap disajikan dalam hasil penelitian. Aktivitas siswa pada saat guru menerangkan maupun pada saat diskusi kelompok berlangsung dipaparkan secara kelompok untuk setiap pertemuan. Aktivitas yang dipaparkan adalah aktivitas yang diamati oleh observer berdasarkan lembar observer yang digunakan baik untuk siswa maupun untuk guru. Sedangkan data hasil tes akhir siklus disajikan dalam bentuk diagram persentase ketuntasan hasil belajar. Setelah data disajikan dalam hasil penelitian kemudian dibahas pada bagian pembahasan.

Tabel 3. Penentuan Skor Klasifikasi Observasi

\begin{tabular}{cc}
\hline Presentase Keberhasilan Tindakan $(\%)$ & Taraf Keberhasilan \\
\hline$x \geq 90$ & Sangat Baik \\
$75 \leq x<90$ & Baik \\
$60 \leq x<75$ & Cukup \\
$40 \leq x<60$ & Kurang \\
$x<40$ & Sangat Kurang \\
\hline
\end{tabular}

Penarikan Kesimpulan, setelah data kualitatif dari guru dan siswa disajikan maka peneliti menarik suatu kesimpulan.

\section{Hasil Penelitian}

Penelitian ini dilakukan setelah melakukan observasi terhadap kegiatan pembelajaran. Selama peneliti melaksanakan Praktik Pengenalan Lapangan (PPL) di SMA Negeri 1 Manokwari kelas XI jurusan Ilmu Pengetahuan Alam (IPA), terlihat bahwa dalam kegiatan pembelajaran guru lebih dominan dalam menyampaikan materi dengan metode ceramah dan siswa hanya mencatat apa yang disampaikan oleh guru. Hal ini mengakibatkan kemampuan siswa dalam memahami suatu konsep matematika sangat lemah, sehingga akan berdampak pada nilai yang diperoleh. Jika seorang pendidik terus menerus melakukan kegiatan pembelajaran dengan cara yang sama, maka hasil belajar siswapun akan tetap sama dan siswa akan mengalami kesulitan dalam menyelesaikan soal-soal matematika. Memperhatikan hal tersebut, maka peneliti melakukan penelitian tindakan kelas dengan penerapan model pembelajaran SFE sebagai upaya untuk meningkatkan hasil belajar siswa kelas XI IPA-7 SMA Negeri 1 Manokwari Tahun Pelajaran 2018/2019 sampai dua siklus.

Berdasarkan analisis data aktivitas siswa, maka diperoleh rata-rata skor aktivitas siswa pada siklus 1 pertemuan pertama dan kedua berturut-turut sebesar "70,58\%" dan "79,41\%" dengan kategori berturut-turut "cukup" dan "baik", dan siklus 2 pertemuan ketiga dan keempat berturut-turut sebesar " $88,23 \%$ dan " 91,17 " dengan kategori berturut-turut "baik" dan "sangat baik". Hasil analisis data mengenai aktivitas belajar siswa disajikan pada tabel 4 berikut.

Tabel 4. Hasil Analisis Data Aktivitas Belajar Siswa

\begin{tabular}{cccc}
\hline Siklus & Pertemuan & Rata-Rata Skor Aktivitas & Taraf Keberhasilan \\
\hline \multirow{2}{*}{1} & 1 & $70,58 \%$ & Cukup \\
& 2 & $79,41 \%$ & Baik \\
\hline \multirow{2}{*}{2} & 3 & $88,23 \%$ & Baik \\
& 4 & $91,17 \%$ & Sangat Baik \\
\hline
\end{tabular}

Berdasarkan hasil pada tabel diatas maka kegiatan siswa dengan menggunakan model pembelajaran SFE pada siklus 1 pertemuan pertama diperoleh $70,58 \%$ dan pertemuan kedua diperoleh $79,41 \%$. Pada siklus 1 siswa belum terbiasa belajar dengan menggunakan model SFE sehingga kegiatan pembelajaran belum optimal. Siswa juga belum bisa mengatur waktu dalam mengerjakan LKK, beberapa siswa bermain-main dan mengganggu teman pada saat diskusi kelompok, siswa dengan kemampuan rendah kurang aktif menyampaikan pendapat serta siswa yg bekerja sama pada saat kuis. Siklus 2 pertemuan ketiga dan keempat diperoleh rata-rata aktivitas siswa 88,23 $\%$ dan $91,17 \%$. Pada hasil siklus 2 pertemuan ketiga mengalami peningkatan,. Peningkatan tersebut diperoleh dari hasil refleksi dari setiap pertemuan sebelumnya, dimana pada pertemuan ketiga guru memberitahu siswa mengenai langkah-langkah model SFE agar siswa tidak mengalami kebingungan, selalu memperingatkan waktu kepada siswa dalam mengerjakan LKK, menegur siswa yang bermain-main. Kemudian guru juga harus memberikan motivasi agar siswa mau berusaha aktif mengeluarkan pendapat, guru lebih memberi perhatian kepada siswa yang kemampuannya rendah dalam memberikan pendapat, guru harus focus rata ke semua siswa sehingga tidak ada 
siswa yang rebut dan guru harus tegas menegur siswa yang kerja sama saat kuis. Pada siklus 2 pertemuan keempat siswa sudah optimal dalam mengikuti pembelajaran, hasil ini didapat berdaarkan refleksi pada pertemuan sebelumnya.

Berdasarkan analisis data aktivitas guru, maka diperoleh rata-rata skor aktivitas guru pada setiap pertemuan sebagai berikut: pertemuan pertama sebesar $82,81 \%$, pertemuan kedua sebesar $84,37 \%$, pertemuan ketiga sebesar 87,5\% dan pertemuan keempat sebesar 93,75\% dengan taraf keberhasilan berturut-turut adalah "baik", "baik', "baik' dan "sangat baik". Hasil analisis data mengenai aktivitas guru disajikan pada tabel 5 berikut.

Tabel 5. Hasil Analisis Data Aktivitas Guru

\begin{tabular}{cccc}
\hline Siklus & Pertemuan & Rata-Rata Skor Aktivitas & Taraf Keberhasilan \\
\hline \multirow{2}{*}{1} & 1 & $82,81 \%$ & Baik \\
& 2 & $84,37 \%$ & Baik \\
\hline \multirow{2}{*}{2} & 3 & $87,75 \%$ & Baik \\
& 4 & $93,75 \%$ & Sangat Baik \\
\hline
\end{tabular}

Berdasarkan hasil tersebut terlihat bahwa guru semakin berusaha memperbaiki pelaksanaan pembelajarannya, sehingga dari siklus 1 pertemuan pertama sampai siklus 2 pertemuan keempat terdapat peningkatan aktivitas mengajar guru.

Pada siklus 1, hasil akhir belajar siswa diperoleh 15 siswa yang memperoleh nilai diatas KKM yaitu 75 dengan presentase sebesar 55,5\%. Sedangkan 12 siswa yang memperoleh nilai dibawah KKM dengan presentase sebesar 44,5\%. Dari seluruh nilai siswa rata-rata yang diperoleh yaitu 67,37 dengan ketuntasan klasikal yang diperoleh yaitu 55,5\%. Hasil ini belum menunjukkan bahwa siklus 1 belum tercapai sesuai kriteria ketuntasan yang diharapkan peneliti, dimana ketuntasan klasikal yang diperoleh $>65 \%$. Hal ini karena siswa belum terbiasa menggunakan model SFE. Kemudian di hasil belajar pada siklus 1, terdapat satu siswa yang memperoleh hasil belajar bertolak belakang dengan dengan hasil kuis pertemuan pertama dan kedua. Selisih nilai tersebut sangat besar. Hal ini dapat dipengaruhi beberapa factor baik itu eksternal maupun internal yang penliti belum ketahui secara pasti.

Pada siklus 2 hasil akhir belajar siswa diperoleh 20 siswa yang memperoleh nilai diatas KKM yaitu 75 dengan presentase sebesar 74,07\%. Sedangkan 7 siswa yang memperoleh nilai dibawah KKM dengan presentase sebesar $25,93 \%$. Dari seluruh nilai siswa rata-rata yang diperoleh yaitu 70,89 dengan ketuntasan klasikal yang diperoleh yaitu $74,07 \%$.

Hasil belajar pada siklus 2 mengalami peningkatan dari siklus 1, hasil ini menunjukkan adanya peningkatan dan telah sesuai dengan criteria yang ditentukan peneliti, dimana hasil ketuntasan klasikal telah $>65 \%$. Hal ini berarti siswa sudah mulai terbiasa menggunkaan model SFE. Secara keseluruhan pada siklus 2 telah berjalan dengan baik.

Berikut tabel presentase perbandingan ketuntasan belajar siklus 1 dan siklus 2 .

Tabel 6. Presentase Perbandingan Ketuntasan Belajar Siklus 1 Dan Siklus 2

\begin{tabular}{cccc}
\hline No & Siklus & Tuntas & Tidak Tuntas \\
\hline 1 & 1 & $55,5 \%$ & $44,5 \%$ \\
2 & 2 & $74,07 \%$ & $25,93 \%$ \\
\hline
\end{tabular}

Dari tabel 6 terlihat bahwa dari siklus 1 sampai siklus 2 ketuntasan belajar terus meningkat sampai $>65 \%$ sesuai dengan kriteria ketuntasan yang telah ditetapkan, sehingga siklus dihentikan. Untuk lebih jelasnya hasil belajar yaitu, nilai rata-rata dan ketuntasan klasikal siswa pada siklus 1 dan siklus 2 dapat dilihat pada tabel 7 berikut.

Tabel 7. Perbandingan Rata-Rata Hasil Belajar dan Ketuntasan Klasikal Pada Siklus 1 dan Siklus 2

\begin{tabular}{ccc}
\hline Siklus & Nilai Rata-Rata & Ketuntasan Klasikal \\
\hline 1 & 67,37 & $55,5 \%$ \\
2 & 70,89 & $74,07 \%$ \\
\hline
\end{tabular}

Berdasarkan tabel diatas, nilai rata-rata dan ketuntasan klasikal mengalami peningkatan dari siklus 1 ke siklus 2. Walaupun peningkatan tidak signifikan namun peningkatan setiap siklusnya dapat menghasilkan kriteria ketuntasn yang hendak dicapai. Secara keseluruhan adanya peningkatan yang terjadi dengan menggunakan model SFE pada setiap siklus. 


\section{Kesimpulan}

Berdasarkan hasil penelitian yang berjudul "Peningkatan Hasil Belajar Siswa Kelas XI IPA-7 SMA Negeri 1 Manokwari Pada Materi Faktorisasi Polinom Melalui Penerapan Model Pembelajaran Kooperatif Tipe Student Facilitator And Explaining" dapat disimpulkan bahwa: hasil belajar siswa kelas XI IPA-7 SMA Negeri 1 Manokwari dengan model Student Facilitator And Explaining (SFE) pada proses kegiatan belajar mengajar materi suku banyak mengalami peningkatan dengan ketuntasan belajar klasikal 55,5\% pada siklus 1 meningkat menjadi $74,07 \%$.

\section{Daftar Pustaka}

Arikunto, S. 2006. Prosedur Penelitian Suatu Pendekatan Praktik. Jogjakarta: Rineka Cipta.

Kakerisa T. 2016. Perbedaan Hasil Belajar Siswa Kelas XII SMA Negeri 7 Ambon yang Diajarkan Dengan Model Pembelajaran Student Facilitator and Explaining dan Model Pembelajaran Konvensional Pada Materi Matriks. Skripsi. FKIP Universitas Pattimura Ambon.

Murfika T. 2011. "Pengaruh model pembelajaran kooperatif metode student facilitator and explaning (SFE) terhadap kemampuan komunikasi matematika siswa SMA". Skripsi. Universitas Islam Negeri.

Purwanto. 2009. Evaluasi Hasil Belajar. Yogyakarta: Pustaka Pelajar

Ruhulessin, S., Ratumanan, T., \& Tamalene, H. (2019). Perbedaan Hasil Belajar Siswa Kelas X SMA

Menggunakan Model Pembelajaran Kooperatif Tipe Student Facilitator and Explaining (SFE) dan Model Pembelajaran Konvensional Pada Materi Trigonometri. Jurnal Pendidikan Matematika (Jupitek), 2(1), 1-6

Suprijono, A. 2009. Cooperative Learning. Yogyakarta: Pustaka belajar.

Suryosubroto B. 2002. Proses Belajar Mengajar Di Sekolah. Jakarta: Rineka Cipta.

Tanujaya, Benidiktus dan Jeinne Mumu. Penelitian Tindakan Kelas. Yogyakarta: Media Akademi. 2016.

Tutuhatunewa, E. 2007. Modul Penelitian Tindakan Kelas. Buku Materi Bidang Studi Pelatihan Dan Latihan Profesi Guru Sertifikasi Guru Dalam Jabatan Rayon 29. Departemen Pendidikan Nasional Panitia Sertifikasi Guru Rayon 29 Maluku. 